\title{
Copper and lead removal by peanut hulls: Equilibrium and kinetic studies
}

\author{
F.D. Oliveira, J.H. Paula, O.M. Freitas, S.A. Figueiredo
}

\begin{abstract}
This research work aims to study the use of peanut hulls, an agricultural and food industry waste, for copper and lead removal through equilibrium and kinetic parameters evaluation. Equilibrium batch studies were per-formed in a batch adsorber. The influence of initial $\mathrm{pH}$ was evaluated (3-5) and it was selected between 4.0 and 4.5. The maximum sorption capacities obtained for the Langmuir model were $0.21 \pm 0.03$ and $0.18 \pm 0.02 \mathrm{mmol} / \mathrm{g}$, respectively for copper and lead. In bi-component systems, competitive sorption of copper and lead was verified, the total amount adsorbed being around $0.21 \mathrm{mmol}$ of metal per gram of material in both mono and bi-component systems. In the kinetic studies equilibrium was reached after 200 min contact time using a $400 \mathrm{rpm}$ stirring rate, achieving $78 \%$ and $58 \%$ removal, in mono-component system, for copper and lead respec- tively. Their removal follows a pseudo-second-order kinetics. These studies show that most of the metals removal occurred in the first 20 min of contact, which shows a good uptake rate in all systems.
\end{abstract}

Keywords: Copper; Lead; Peanut hulls; Sorption;Wastewater

\section{Introduction}

There are several industries responsible for the discharge of wastewaters containing heavy metals, mining and mineral processing, pigments manufacture, the painting and photographic industries and metal-working and finishing processes (electroplating). Since metals are non-biodegradable, and may be bio-accumulated in living tissues, thus becoming concentrated throughout the food chain, until toxic concentrations are achieved, their removal from wastewaters is nowadays legally imposed.

The treatment of effluents containing heavy metals includes chemical precipitation, mem- brane filtration, electrolytic methods, ion exchange and adsorption. These methods have been found to be limited, since they often involve high capital and operational costs and may be associated with the generation of 
secondary wastes which present treatment problems, such as large quantity of sludge generated by precipitation processes. On the other hand, ion exchange, reverse osmosis and adsorption are more attractive processes because the metals can be recovered. Regeneration and reusability of the sorbent material must also be considered when assessing the efficiency and feasibility of a treatment process. If the sorbent can be regenerated through a desorption cycle (dissolution in adequate eluent, e.g., strong acid) without destruction, the process will become more lucrative. The successive regene- rations of sorbents decrease their efficiency, there- fore limiting the number of cycles. After that they may be considered wastes and need to be further disposed. Another alternative is the use of destruc- tive techniques such as incineration.

Reverse osmosis and ion exchange do not seem to be economically attractive because of their relatively high investment and operational costs $\left(1.5-15 \$ / \mathrm{dm}^{3}\right)$ [1]. Activated carbon has been recognized as a highly effective adsorbent for the removal of heavy metal-ion but due to the high cost of this material $\left(1-2 \$ / \mathrm{dm}^{3}\right)$ [1], the process is too expensive to be applied by small and medium scale industries [2, 3]. The biosorbents can usually be obtained free of charge from the respective producers since they sometimes present disposal problems. The only costs to be considered are those of transport and grinding. For peanut hulls a cost of $0.0015 \$$ / $\mathrm{dm}^{3}$ was estimated by Brown et al. [4].

So research has recently been directed to the study of alternative low-cost adsorbents. Materi- als locally available in large quantities such as natural materials, agricultural waste or industrial byproducts can be used as adsorbents with little processing [3].

The sorption characteristics of the agricul- tural waste materials derive from their constitu-

ent polymers (in approximately decreasing order of abundance): cellulose, hemicelluloses, pectin, lignin and protein [2]. Cellulosic surface becomes partially negatively charged when immersed in water and, therefore, possesses coulombic interaction with cationic species $[5,6]$, contributing to the high binding capacities of these materials.

In this work, peanut hulls, one of the most abundant food industry waste products, were tested for copper and lead removal through equilibrium and kinetic parameters evaluation. This material, due to its easy availability, has been studied by some researchers for metals removal in mono-component systems [2-4]. The present study deals not only with mono-component systems (copper and lead) but also with the respective bicomponent system, allowing their comparison.

\section{Materials and methods}

\subsection{Sorbent preparation}

The peanut hulls were ground and sieved. The chemical and physical characteristics [4] are shown in Table 1. All experiments were per- formed with particles of grain size between 0.710 and 1.000 $\mathrm{mm}$.

Table 1

Characteristics of raw peanut hulls (adapted from Brown et al. [4])

\begin{tabular}{cll}
\hline & moisture & $8-10 \%$ \\
& protein & $6-7 \%$ \\
Chemical & fat & $1 \%$ \\
characteristics & fiber & $60-70 \%$ \\
& cellulose & $34-45 \%$ \\
& lignin & $27-33 \%$ \\
& ash & $2-4 \%$ \\
\hline & & \\
\hline \multirow{2}{*}{ Physical } & Bulk density & $5-7 \mathrm{lb} / \mathrm{ft}^{3}$ \\
& $\begin{array}{l}\text { Porosity } \\
\text { 61.7\% characteristics }\end{array}$ & \\
& Solubility in $\mathrm{H} 2 \mathrm{O}$ & \\
& $0.74 \%$ & $2.25 \%$ \\
& Solybility in 0.25 & \\
& $\mathrm{HCl}$ & 6.68 \\
\hline
\end{tabular}




\subsection{Heavy metal solutions}

Analytical grade salts $\left(\mathrm{Cu}\left(\mathrm{NO}_{3}\right)_{2} \cdot 2 \frac{1}{2} \mathrm{H}_{2} \mathrm{O}\right.$ and $\left.\mathrm{Pb}\left(\mathrm{NO}_{3}\right)_{2}\right)$ were used to prepare solutions (concentrations $10-100 \mathrm{mg} / \mathrm{L}$ ) of $\mathrm{Cu}(\mathrm{II})$ and $\mathrm{Pb}(\mathrm{II})$. The $\mathrm{pH}$ of each solution was measured (Anatron $\mathrm{pH} 300$ ) and adjusted to the desired value using diluted solutions of $\mathrm{HCl}$ and $\mathrm{NaOH}$. During the experiments no effort was made to control the solution $\mathrm{pH}$ and no ionic strength was imposed, as in other research works [7].

\subsection{Equilibrium studies}

The equilibrium adsorption isotherms were determined, at 208C, using an orbital P-Selecta Rotabit shaker into a refrigerated incubator P-Selecta Hotcold-M. A set of $100 \mathrm{~mL}$ Erlen- meyers (with cap) containing $50.00 \mathrm{~mL}$ of solution and different amounts of peanut hulls (0.1-0.6 g) were shaken at $120 \mathrm{rpm}$ during 9 days, contact time enough to reach equilibrium. For each metal solution a blank test was run, under the same conditions. At the end, samples were filtrated (cellulose nitrate fibber filters,

$0.45 \mathrm{~mm}$ pore size diameter), the metal concentration was determined by atomic absorption spectrometry (AAS) using AAnalyst 200 Perkin Elmer Instruments and $\mathrm{pH}$ was evaluated (Anatron pH300).

\subsection{Kinetic studies}

Kinetic experiments were conducted in a batch continuously stirred vessel (400 rpm) con- taining $2.0 \mathrm{~L}$ of metal solution at initial $\mathrm{pH} 4.0$ before adding $3.00 \mathrm{~g}$ of peanut hulls. Samples for the determination of the residual metal-ion concentrations in the solution were taken at predetermined time intervals, during approximately 3 h. All experiments were conducted at room temperature (208C). The samples were filtered (cellulose nitrate fibber filters, $0.45 \mathrm{~mm}$ pore size diameter) and the metal concentration was evaluated by AAS (AAnalyst 200 Perkin Elmer Instruments).

\section{Results and discussion}

Equilibrium isotherms at different $\mathrm{pH}$ values and kinetic experiments were performed for lead and copper. The removal in bi-component systems, containing both copper and lead, was also compared with mono-component systems concerning both equilibrium and kinetics.

\subsection{Equilibrium studies}

In order to study the influence of $\mathrm{pH}$, equilibrium isotherms at different $\mathrm{pH}$ values in the range from 3 to 5. Reddad et al. [7] also obtained their best results for copper and lead removal in the range of 3.5-5.5 using sugar beet pulp, another agricultural waste. The experimental $\mathrm{pH}$ values used were 3.2 and 4.0, for copper;

2.9 and 4.6 , for lead.

Although there was no special care to main- tain $\mathrm{pH}$ during the course of the experiments, the maximum increase observed (less than 0.5 for the higher adsorbent concentration) was not considered significant. Moreover, when apply- ing this kind of sorbents to treat large volume of industrial effluents, it may be difficult to accurately adjust the $\mathrm{pH}$ value.

The Langmuir and Freundlich equilibrium models were chosen to fit the experimental results and are represented in Fig. 1. The shape of the isotherms shows that, as the adsorbent concentration increases, adsorption generally increases, but the amount adsorbed per unit mass of the adsorbent decreases considerably, as observed by Aydin et al. [8], which is attrib- uted to adsorption sites remaining unsaturated during the sorption process.

The models parameters were obtained by nonlinear least-squares regression analysis using Fig.P version 2.98 software from BIOSOFT and are presented in Table 2 . The performances 


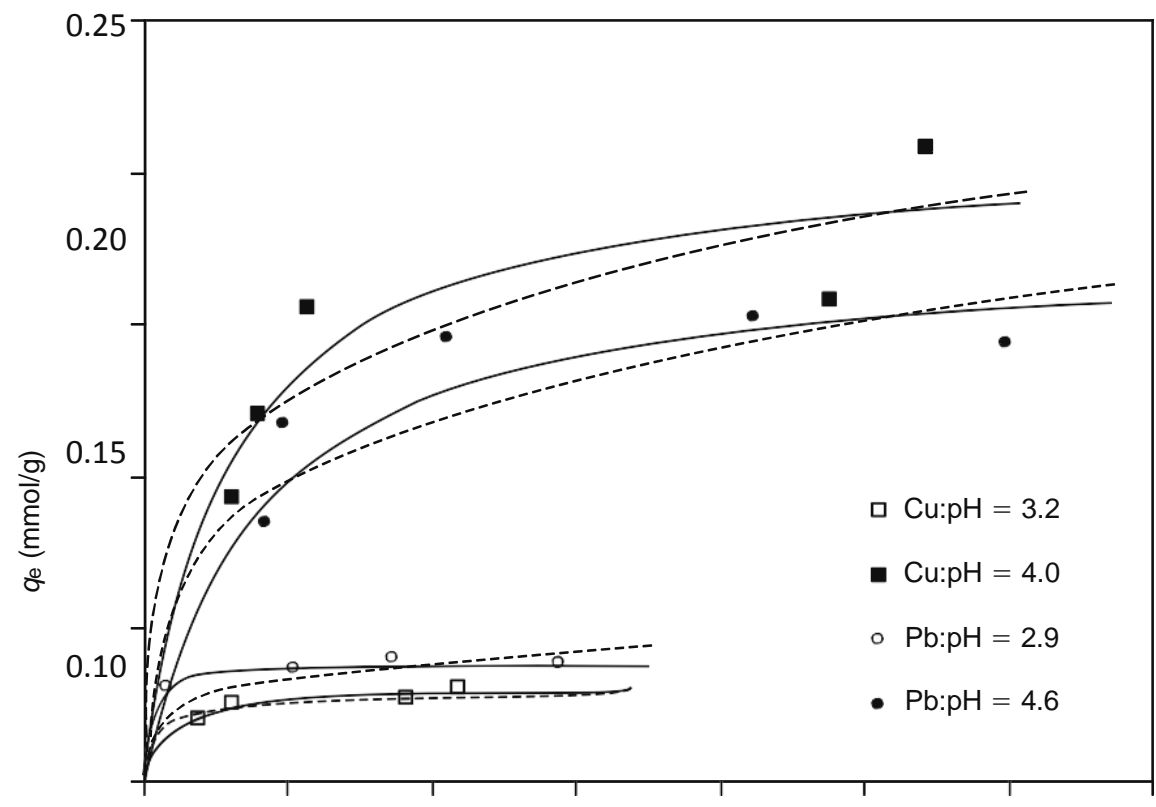

0.05

0.00

$\begin{array}{llllllll}0.00 & 0.02 & 0.04 & 0.06 & 0.08 & 0.10 & 0.12 & 0.14\end{array}$

$\mathrm{Ce}(\mathrm{mmol} / \mathrm{L})$

Fig. 1. Experimental results of the equilibrium studies for $\mathrm{Cu}(\mathrm{II})$ and $\mathrm{Pb}(\mathrm{II})$ using peanut hulls. Langmuir (-) and Freundlich (- - ) models fits.

of the models were compared using an F-test, based on model variances. In the conditions tested, both models fit well the experimental data with average probability level of $90 \%$, except for lead at $\mathrm{pH}$ 2.9. Concerning the fitness of the models to the experimental data, the best fits were obtained for Langmuir model, as verified by Reddad et al. [7] for copper and lead.
Comparing the Langmuir maximum sorption capacities, qL (Table 2), an increase in capacity for higher $\mathrm{pH}$ values, 4.0 and 4.6, respectively for copper and lead can be observed. The same effect was observed by Aydin et al. [8] for copper ions removal using agricultural wastes. They explain that at lower $\mathrm{pH}$ values, the $\mathrm{H}_{3} \mathrm{O}^{+}$ions compete with the metal ions for the exchange sites in the adsorbent. There is an

Table 2

Langmuir and Freundlich model parameters for copper(II) and lead(II) sorption on peanut hulls

\begin{tabular}{|c|c|c|c|c|c|c|c|c|c|}
\hline \multirow[b]{2}{*}{ Metal } & \multirow[b]{2}{*}{$\mathrm{pH}$} & \multicolumn{4}{|c|}{ Langmuir isotherm: $q_{e} e^{1 / 4} \frac{b q q_{L} C_{e}}{1 p b C_{e}}$} & \multicolumn{4}{|c|}{ Freundlich isotherm: $q_{\mathrm{e}}{ }^{1 / 4} K_{\mathrm{F}} C_{\mathrm{e}}^{+}$} \\
\hline & & $q \mathrm{~L}(\mathrm{mmol} / \mathrm{g})$ & $b(\mathrm{~L} / \mathrm{mmol})$ & $s^{2}$ & $r$ & $\begin{array}{l}K_{\mathrm{F}}((\mathrm{mmol} / \mathrm{g}) \\
\left.(\mathrm{L} / \mathrm{mmol})^{1 / n}\right)\end{array}$ & $n$ & $s^{2}$ & $r$ \\
\hline $\mathrm{Cu}$ & $\begin{array}{l}3.2 \\
4.0\end{array}$ & $\begin{array}{l}0.032 \pm 0.002 \\
0.21 \pm 0.03\end{array}$ & $\begin{array}{l}260 \pm 81 \\
86 \pm 40\end{array}$ & $\begin{array}{l}3.33 \times 10^{-6} \\
5.57 \times 10^{-4}\end{array}$ & $\begin{array}{l}0.928 \\
0.882\end{array}$ & $\begin{array}{l}0.049 \pm 0.008 \\
0.32 \pm 0.09\end{array}$ & $\begin{array}{l}6 \pm 2 \\
4 \pm 2\end{array}$ & $\begin{array}{l}4.44 \times 10^{-6} \\
6.71 \times 10^{-4}\end{array}$ & 0.856 \\
\hline
\end{tabular}


$\begin{array}{lllllll}\mathrm{Pb} & 2.9 & 0.040 \pm 0.001 & 1082 \pm 275 & 1.82 \times 10^{-0} & 0.959 & 0.08 \pm 0.03\end{array}$

$5 \pm 2 \quad 4.09 \times 10^{-\supset} \quad 0.910$

$4.6 \quad 0.18 \pm 0.02$

$65 \pm 27$

$3.18 \times 10^{-4} \quad 0.892 \quad 0.28 \pm 0.08$

$4 \pm 1 \quad 4.92 \times 10^{-4} 0.825$ 
increase in metal-ions uptake as the $\mathrm{pH}$ value increases from 2 to 6 . After that, the sharp decrease of adsorption is due to the beginning of hydroxides precipitation. The same phenom- enon may occur with lead ions.

Operating with $\mathrm{pH}$ values between 4 and 4.5 was considered adequate for the systems copper and lead / peanut hulls. As $\mathrm{pH}$ values tend to increase during the experiments (less than 0.5), mainly for the highest peanut hulls concentrations, the use of $\mathrm{pH}$ values above 6 prevent copper or lead hydroxides precipitation.

Lead is better removed from aqueous solutions than copper, when comparing the Langmuir maximum capacities obtained for each metal, 0.21 \pm 0.03 and $0.18 \pm 0.02 \mathrm{mmol} / \mathrm{g}$, respectively for copper and lead. These confi- dence intervals are in the neighborhood of the values presented by Brown et al. [4] for the same systems, respectively 0.13 and $0.14 \mathrm{mmol} / \mathrm{g}$. They are higher than those obtained by An et al. [9] for granular activated carbons (GAC) and powder activated carbons (PAC), however lower than the commercial resins [7] presented in Table 3.

The expression of capacity values in mass is important for wastewater treatment because treated effluents should reach concentrations below the regulation limits. Accordingly to a relative comparison based on the grams of metal ions removed per dollar of media cost of resins, are much more expensive than peanut hulls, by a factor of 64.5 relative to one gram copper removal and by a factor 106.5 when dealing with lead removal. This analysis, presented by Brown et al. [4], does not take into account the costs associated with regeneration, replacement, disposal, and so on, which are common to both materials.

In order to evaluate the presence of other metallic species in the solution that may compete for the same active sites, bi-component equilibrium experiments were performed. The comparison of Langmuir maximum equilibrium capacity obtained in mono-component system with the maximum experimental equilibrium capacity obtained in bi-component system is presented in Fig. 2. The values of peanut hulls maximum capacities, in mono-component aque- ous solutions, are higher for copper than for lead. However, in bi-component solutions, using a molar ratio of $\mathrm{Cu}: \mathrm{Pb}$ of 0.8 , the opposite is veri- fied. This behavior might indicate a higher affin- ity for lead than for copper, which was also verified by Pagnanelli et al. [10]. They explain that the specific uptake of a metal is proportional to its hydrolysis constants $(\log K \mathrm{~Pb}=-7.71>\log K \mathrm{Cu}=-8.00)$. In a binary system, the most acidic ion is less affected by the presence of other less acidic metals and is the most

Table 3

Comparison of metal sorption capacities (adapted from Reddad et al. [7])

\begin{tabular}{|c|c|c|c|c|c|}
\hline Sorbent & & $\mathrm{Cu}(\mathrm{II})(\mathrm{mmol} / \mathrm{g})$ & $\mathrm{Pb}(\mathrm{II})$ (mmol/g) & Conditions & Referenc \\
\hline \multirow[t]{2}{*}{ Activated carbon } & $\begin{array}{l}\mathrm{GAC}\left(A \mathrm{c}=1032.8 \mathrm{~m}^{2} / \mathrm{g}\right. \\
d \mathrm{p}=246.8 \mathrm{~nm})\end{array}$ & 0.080 & 0.080 & pH 5; 308C & [9] \\
\hline & $\begin{array}{l}\text { PAC (iodine number }=1050 \\
\mathrm{mg} / \mathrm{g} \text { ) }\end{array}$ & 0.070 & 0.130 & $\mathrm{pH} 5 ; 308 \mathrm{C}$ & [9] \\
\hline \multirow[t]{4}{*}{ Commercial resins } & Duolite GT-73 & 0.97 & 0.59 & $\mathrm{pH} 4.8$ & {$[10]$} \\
\hline & Amberlite IRC-718 & 2.00 & 1.40 & $\mathrm{pH} 4.8$ & [10] \\
\hline & Amberlite 200 & 1.40 & 1.70 & $\mathrm{pH} 4.8$ & [10] \\
\hline & Lewatit TP 207 & 1.34 & 0.96 & $\ldots$ & [4] \\
\hline
\end{tabular}


influencing the other metal uptake. This experimental behavior is also in accordance with other criteria, related with the binding strength of metals, presented in Table 4: larger Shannon crystal radii of ions $\left(r_{\text {cryst }}\right)$, with the same charge $(z)$ as lead ions are less strongly hydrated ( $r$ hyd $)$ and are preferably accumulated at the interface; moreover, looking at the com- bined factors, parameters for ionic bonding strength $\left(z^{2} /\right.$ hyd $)$ and for ionic bond character

$(D x)$ and fraction of ionic bond character (z), it is observed that the ionic character of binding is stronger for lead than for copper; which shows stronger covalent character of binding than lead, according to the combined factor parameter for total binding strength $(x)$.

It is also observed, in Fig. 2, that the total amount of metals sorbed in bi-component system is almost the same as that obtained for copper in mono-component system, showing a competitive sorption of copper and lead.

\subsection{Kinetic studies}

Although equilibrium studies are important to know the maximum amount of metal that can be removed by a given material, the kinetic of the process limits the rate at which equili- brium state can be reached, what is usually the

\section{Table 4}

Parameters characterizing the binding strength of copper and lead (adapted from Schiewer [12])

\begin{tabular}{|c|c|c|}
\hline & $\mathrm{Cu}$ & $\mathrm{Pb}$ \\
\hline$z$ & 2 & 2 \\
\hline $\begin{array}{l}\text { rcryst } \\
1.19\end{array}$ & 0.73 & \\
\hline $\begin{array}{l}\text { rhyd } \\
4.01\end{array}$ & 4.19 & \\
\hline$x$ m & 1.90 & 1.8 \\
\hline $\begin{array}{l}z^{2} / \text { rhyd } \\
1.00\end{array}$ & 0.95 & \\
\hline$\left(1 / 41-\exp \left(-L \mid x^{2}{ }_{4}\right)\right.$ & $\begin{array}{l}1.5 \\
0.43\end{array}$ & 1.7 \\
\hline${ }_{1 / 4}^{0.51}\left(z_{\text {rhyd }}\right) / / 1-\exp -L^{\prime} f^{\prime}$ & 2.22 & \\
\hline
\end{tabular}

critical in operation conditions, because contact time is sometimes not enough to meet the equilibrium state. This depends on the mass transfer resistances that control the adsorption process. Considering the high stirring rate used in this study, $400 \mathrm{rpm}$, external mass transfer resistance was minimized and the internal diffusion in the adsorbent pores could be the dominant resistance; however, if the adsorbent's pores are easily accessed by metal ions, the sorption reaction could be the limiting step.

In order to test this hypothesis pseudo-first and pseudo-second-order models were used to fit the experimental results obtained for copper and lead removal both in mono-component and bicomponent systems (Fig. 3). The bi- component study was performed to evaluate if there are changes in the adsorption rate when other metals are present in solution.

The pseudo-first and pseudo-second-order model parameters are presented in Table 5, and were calculated by nonlinear least-squares regression analysis using Fig.P version 2.98 software from BIOSOFT. The values used as equilibrium concentrations in the solid phase, one of the parameters in both models, were the experimental ones. It was verified, when the regressions were performed with two unknown parameters, that the experimental values belong to the confidence interval of the adjusted parameters.

In Fig. 3 equilibrium was reached after $200 \mathrm{~min}$, achieving, respectively in mono and bi-component systems: $78 \%$ and $35 \%$ removal for copper; $58 \%$ and $59 \%$ removal for lead. Nevertheless most of the metals removal occurred in the first $20 \mathrm{~min}$, approximately $70 \%$ and $75 \%$ of the metal removal occurred, respectively for copper and lead, which shows a good uptake rate in all systems. These removal rates could be improved, namely using higher adsorbent concentration. Consequently, for

industrial purposes using 30 min contact time seems adequate. Depending on the initial 


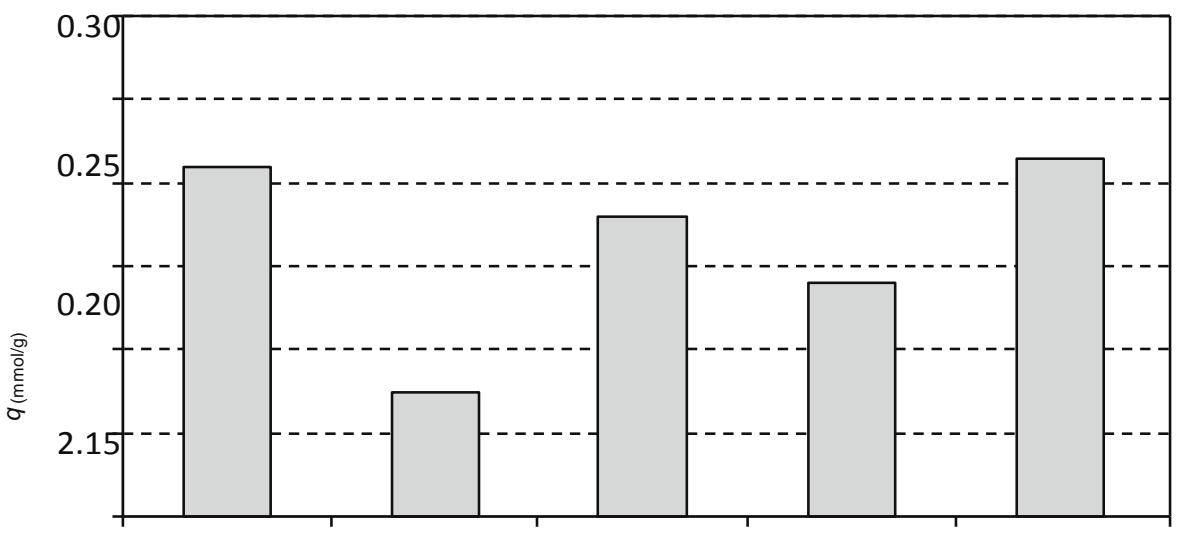

0.10

0.05

0.00
$\mathrm{Cu}$
$\mathrm{Cu}(\mathrm{Cu}: \mathrm{Pb})$
$\mathrm{Pb}$
$\mathrm{Pb}(\mathrm{Cu}: \mathrm{Pb}) \quad \mathrm{Cu}+\mathrm{Pb}(\mathrm{Cu}: \mathrm{Pb})$

Fig. 2. Comparison of maximum equilibrium solid phase concentration for $\mathrm{Cu}(\mathrm{II})$ and $\mathrm{Pb}(\mathrm{II})$ in mono and bicomponent aqueous solutions $(0.30 \mathrm{mmol} / \mathrm{L}$ of copper and $0.37 \mathrm{mmol} / \mathrm{L}$ of lead) using peanut hulls.

concentration of the metals, the removal efficiencies achieved may not be enough to reach the legal discharge limits, especially for high metals concentration. In these situations the use of the sorbent material into a predimensioned packed column would guarantee a rejection of treated wastewaters in accordance with the legislation.

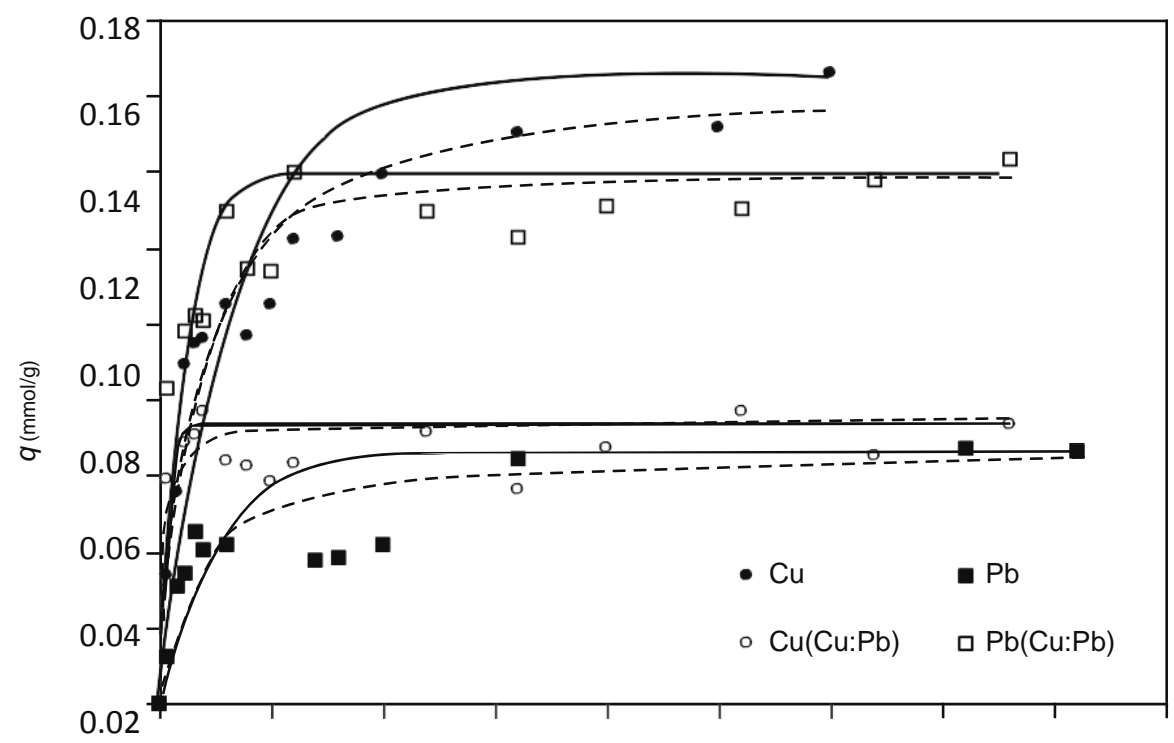

0.00 
Time (min)

Fig. 3. Experimental results of the kinetic studies for $\mathrm{Cu}(\mathrm{II})$ and $\mathrm{Pb}(\mathrm{II})$ in mono and bi-component aqueous solutions $(0.33 \mathrm{mmol} / \mathrm{L}$ of copper and $0.38 \mathrm{mmol} / \mathrm{L}$ of lead) using peanut hulls. Pseudo-first-order $(-)$ and pseudo-second-order (-- -) models fits. 
The performances of the two models were also compared using an F-test. For both copper and lead removal the pseudo-second-order model was the best to fit in both mono and bi-component solutions. These last findings are in accordance with other studies where metals removal by agricultural wastes $[8,11]$ or other biomaterials $[12,13]$, follows usually pseudo- second-order kinetics, which means that the sorption kinetics of these systems depends on the solid phase concentration in the equilibrium and sorption capacity is proportional to the num- ber of active sites occupied on the sorbent, two. The sorption ability of copper and lead by peanut hulls may be attributed to its components, namely cellulose, hemicelluloses, pectin, lignin and protein [2]. The negatively charged cellulo- sic surface shows coulombic interaction with cationic species, in aqueous solution $[5,6]$. Their efficient removal may also be related with the presence of carbonyl and hydroxyl groups in their composition. Carbonyl groups are present in fats, lignin, protein and pectin and hydroxyl groups are present in cellulose and lignin. The oxygen of each carbonyl and hydroxyl group is considered a strong Lewis base because of the presence of its vacant double electrons, which could bind to a metal cation (chemical species with an electron deficit) forming a complex of coordination [14]. The same might occur with the nitrogen of amides present in proteins.

\section{Conclusions}

In this work, peanut hulls, one of the most abundant food industry waste products, were tested for copper and lead removal. This material can be used as adsorbent with little processing.

Equilibrium batch studies allowed the selection of initial $\mathrm{pH}$ for operation, between

4.0 and 4.5. The maximum sorption capacities obtained for the Langmuir model were $0.21 \pm$ 0.03 and $0.18 \pm 0.02 \mathrm{mmol} / \mathrm{g}$, respectively for 
copper and lead, which are higher than those obtained for GAC and PAC, but lower than those reached by ion-exchange resins, these are however much more expensive. In bi- component systems, a competitive sorption of copper and lead was verified.

Copper and lead removal by peanut hulls follows a pseudo-second-order kinetics. These studies show that most of the metals removal occurred in the first $20 \mathrm{~min}$ of contact, which shows a good uptake rate in all systems. For industrial purposes using 30 min contact time, at $400 \mathrm{rpm}$ stirring rate, seems adequate for wastewater treatment of small and medium- scale industries.

Thus the use of this waste material could be cost-effective and might contribute to the sustainability of the environment.

\section{Nomenclature}

\begin{tabular}{|c|c|}
\hline $\begin{array}{l}\text { As } \\
\left(\mathrm{m}^{2} / \mathrm{g}\right)\end{array}$ & specific surface area \\
\hline$b$ & $\begin{array}{l}\text { Langmuir equation } \\
\text { constant (L } \\
\text { solution/mmol metal) }\end{array}$ \\
\hline$C e$ & experimental equilibrium liquid \\
\hline & $\begin{array}{l}\text { phase concentration } \quad(\mathrm{mmol} \\
\text { metal/L solution) }\end{array}$ \\
\hline$C_{\mathrm{i}}$ & $\begin{array}{l}\text { initial liquid phase } \\
\text { concentration (mmol metal/L } \\
\text { solution) }\end{array}$ \\
\hline$d p$ & particle average diameter $(\mathrm{nm})$ \\
\hline$k 1$ & pseudo-first order kinetic \\
\hline & constant $\left(\min ^{-1}\right)$ \\
\hline$k 2$ & $\begin{array}{l}\text { pseudo-second order kinetic } \\
\text { constant (mmol metal/(g } \\
\text { material per } \mathrm{min}))\end{array}$ \\
\hline$K \mathrm{~F}$ & $\begin{array}{l}\text { Freundlich constant ( } \mathrm{mmol} \text { metal/g } \\
\text { material) (L solution } / \mathrm{mmol} \\
\text { metal) }(1 / n)\end{array}$ \\
\hline$n$ & Freundlich constant \\
\hline$q$ & $\begin{array}{l}\text { experimental solid phase } \\
\text { concentration (mmolmetal/g } \\
\text { material) }\end{array}$ \\
\hline$q \mathrm{e}$ & $\begin{array}{l}\text { experimental equilibrium solid phase } \\
\text { concentration ( } \mathrm{mmol} \text { metal/g } \\
\text { material) }\end{array}$ \\
\hline$q \mathrm{~L}$ & Langmuir constant, corresponding \\
\hline & $\begin{array}{l}\text { to the adsorbent maximum } \\
\text { capacity (monolayer saturation) } \\
\text { (mmol metal/g material) } \\
\text { correlation to model }\end{array}$ \\
\hline
\end{tabular}

rcryst Shannon crystal radii $\left(A^{\circ}\right)$ 


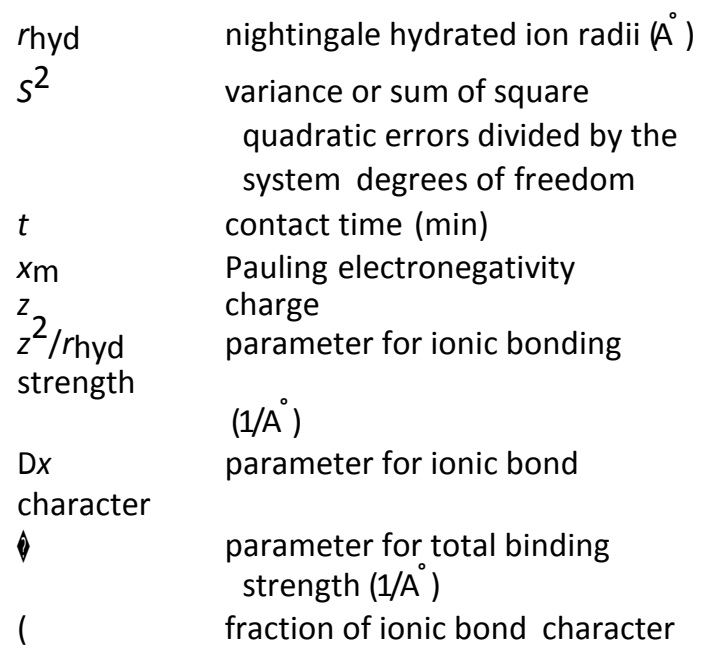

\section{References}

[1] Watersurplus, http://www.watersurplus.com (Consulted in July 2008).

[2] U. Kumar. Agricultural products and byproducts as a low cost adsorbent for heavy metal removal from water and wastewater: A review. Sci. Res. Essay 2 (2006) 33-37.

[3] T. A. Kurniawan, G. Y.S. Chan, W.-h. Lo and S. Babel. Comparisons of low-cost adsorbents for treating wastewaters laden with heavy metals. Sci. Total Environ. 366 (2006) 409426.

[4] P. Brown, I. A. Jefcoat, D. Parrish, S. Gill and E. Graham. Evaluation of the adsorp- tive capacity of peanut hull pellets for heavy metals in solution. Adv. Environ. Res. 4(1) (2000) 19-29.

[5] J. A. Laszlo and F. R. Dintzis. Crop resi- dues as ion-exchange materials: Treatment of soybean hull and sugar beet fiber (pulp) with epichlorohydrin to improve cationexchange capacity and physical stability. J. Appl. Poly. Sci. 52 (1994) 531-538.

[6] G. McKay, M. El Geundi and M. M. Nas- sar. Equilibrium studies during the removal of dyestuffs from aqueous solutions using Bagasse pith. Water Res. 21 (1987) 1513-1520. 
[7] Z. Reddad, C. Ge'rente, Y. Andre's and P. Cloirec. Adsorption of several metal ions onto a lowcost biosorbent: Kinetic and equilibrium studies. Environ. Sci. Technol. 36 (2002) 20672073.

[8] H. Aydin, Y. Bulut and Ç. Yerlikaya. Removal of copper (II) from aqueous solu- tion by adsorption onto low-cost adsorbents. J. Environ. Manage. 87 (2008) 37-45.

[9] H. K. An, B. Y. Park and D. S. Kim. Crab shell for the removal of heavy metals from aqueous solution. Water Res. 35(15) (2001) 35513556.

[10] F. Pagnanelli, A. Esposito and F. Veglio', Multimetallic modelling for biosorption of binary systems. Water Res. 36 (2002) 4095-4105.

[11] G. Mckay and Y. S. Ho. Pseudo-second order model for sorption processes. Proc- ess Biochem. 34 (1999) 451-465.

[12] O. M. M. Freitas, R. J. E. Martins, C. M. DelerueMatos and R. A. R. Boaventura. Removal of $\mathrm{Cd}(\mathrm{II}), \mathrm{Zn}(\mathrm{II})$ and $\mathrm{Pb}(\mathrm{II})$ from aqueous solutions by brown marine macro algae: Kinetic modelling. J. Hazard. Mater. 153 (2008) 493-501.

[13] V. J. P. Vilar, C. M. S. Botelho and R. A. R. Boaventura. Copper removal by algae Gelidium, agar extraction algal waste and granulated algal waste: Kinetics and equilibrium. Bioresour. Technol. 99 (2008) 750-762.

[14] M. N. V. Prasad and H. Freitas. Removal of toxic metals from solution by leaf, stem and root phytomass of Quercus ilex

L. (holly oak). Environ. Pollut. 110 (2000) 277-283.

[15] T. Vaughan, C. W. Seo and W. E. Marshall. Removal of selected metal ions from aqueous solutions using modified corn cobbs. Bioresour. Technol. 78 (2001) 133-139.

[16] S. Schiewer. Multi-metal ion exchange in biosorption. Ph.D. thesis, Department of Chemical Engineering, McGill University, Montreal, Canada (1996). 